\title{
P342: Patient safety and risk management in health center in Niger
}

\author{
H Djibo $^{1 *}$, O Diakite ${ }^{2}$, M Adamou $^{2}$ \\ From 2nd International Conference on Prevention and Infection Control (ICPIC 2013) \\ Geneva, Switzerland. 25-28 June 2013
}

\section{Introduction}

The situation of adverse events related to health care in Niger like developing countries (DCs) remains poorly studied and therefore poorly managed.

\section{Objectives}

For the hospital, it is a challenge for the future to the extent that this approach aims to: improve the safety of patients and staff, preserve the image of the institution, reduce the direct impact of risks and associated costs, protect workers against the risk of litigation.

\section{Methods}

We performed at the National Hospital Lamordé, a prospective cross-sectional study. Pediatric services, pneumophtisiology, urology, pediatric surgery, emergency and we have served as framework for this study. In this survey we asked health workers and users of the hospital. Then we observed working sessions of participants.

\section{Results}

This work has revealed that $60 \%$ of workers have experienced patients who experienced adverse events during their hospital stay, $65.7 \%$ have once had an accident with exposure to blood. Hand washing is not systematic in $45 \%$ of cases, the disposable equipment was sometimes used in $25.7 \%$. It was also found that immunization against hepatitis B was very poor $14.3 \%$, while blood exposure accidents were not zero. Insufficient training of participants in hygiene and and safety of patients in $37.1 \%$. All services have seen at least one needle collector, pedal and manually opening bins.

${ }^{1}$ Department of Public Health, Faculty of Health Sciences, Niamey, Niger

Full list of author information is available at the end of the article

\section{Conclusion}

The situation in most of our developing countries deserves special attention. Indeed, the deficiencies in the management of waste and the fight against infections associated with acts of care, supply and quality unreliable drugs, inefficient staff, inadequately motivated and poorly trained and are problems in finance sector are accentuated iatrogenic problems in these countries compared to industrialized countries (WHO, 2002).

\section{Disclosure of interest}

None declared.

\section{Author details}

'Department of Public Health, Faculty of Health Sciences, Niamey, Niger. ${ }^{2}$ Physician Health District, Niamey, Niger.

Published: 20 June 2013

doi:10.1186/2047-2994-2-S1-P342

Cite this article as: Djibo et al:: P342: Patient safety and risk management in health center in Niger. Antimicrobial Resistance and Infection Control 2013 2(Suppl 1):P342.

Submit your next manuscript to BioMed Central and take full advantage of:

- Convenient online submission

- Thorough peer review

- No space constraints or color figure charges

- Immediate publication on acceptance

- Inclusion in PubMed, CAS, Scopus and Google Scholar

- Research which is freely available for redistribution
C BioMed Central

(0 2013 Djibo et al; licensee BioMed Central Ltd. This is an Open Access article distributed under the terms of the Creative Commons Attribution License (http://creativecommons.org/licenses/by/2.0), which permits unrestricted use, distribution, and reproduction in any medium, provided the original work is properly cited. 